\title{
PENGARUH VARIASI KUAT ARUS LISTRIK DAN WAKTU ELECTROPLATING NICKEL-CHROME TERHADAP KETEBALAN LAPISAN PADA PERMUKAAN BAJA KARBON RENDAH
}

\author{
${ }^{(1)}$ Hb. Sukarjo, (2) Soelarso Pani \\ ${ }^{(1,2)}$ Prodi Teknik Mesin Universitas Proklamasi 45 Yogyakarta \\ ${ }^{(1)}$ Email: heribertus_sukarjo@yahoo.com \\ Jl. Proklamasi No.1 Babarsari Yogyakarta
}

\begin{abstract}
The development and progress of science and technology in the metal plating industry has become a field of work that is experiencing rapid advances ranging from the type of coating, a coating material that is used, and the results of lapisannya. The metal plating industry needs not only demand resistance to corrosion, but also the strength of the material, has a beautiful appearance, and has a high economic value. one of them, namely by means of electroplating coating. The purpose of this research is to know the influence of variations in the strength of an electric current and time of electroplating nickel - chrome against the thickness of the surface layer of low carbon steel. The benefits of this research are expected to add to the knowledge about the coating on the process of electroplating nickel-chrome and can apply it. In the activities of this research material used is low carbon steel plates with a size $40 \mathrm{~mm} \times 25 \mathrm{~mm} \times 1 \mathrm{~mm}$ with the number 27 specimens are coated using electroplating method with the variation of strength of electric current of 0,5A, 1A, 1,5A and time electroplating 10 minutes, 15 minutes, 20 minutes. Testing done next the thickness of the layer. Results of the study showed that the highest hardness of nickel-chrome electroplating process occurs on a variation of value the highest layer thickness variation in the strength of the current $1.5 \mathrm{~A}$ long coating 20 minute $1.97 \mu \mathrm{m}$.
\end{abstract}

Keywords: Electroplating, nickel, chrome.

\section{PENDAHULUAN}

Perkembangan dan kemajuan ilmu pengetahuan serta teknologi pada industri pelapisan logam telah menjadi bidang pekerjaan yang mengalami kemajuan yang sangat pesat mulai dari jenis pelapisan, bahan pelapis yang digunakan, hingga hasil lapisannya. Tersedianya material logam yang mempunyai keunggulan sangat diperlukan untuk menjadi bahan dasar dari komponen pelapisan logam. Kebutuhan industri pelapisan logam tidak hanya menuntut ketahanan terhadap korosi, namun juga kekuatan dari material, memiliki penampilan yang indah, serta memiliki nilai ekonomis yang tinggi. Beberapa macam pelapisan dapat digunakan untuk mencegah atau memperlambat tingkat kerusakan serta meningkatkan kekuatan mekanis logam tersebut, salah satunya yaitu dengan cara pelapisan electroplating (Deviana, 2014).

Proses electroplating dikenal di masyarakat dengan berbagai macam istilah. Misalnya saja sampai saat ini di beberapa daerah untuk proses electroplating masih menggunakan istilah proses galvanis, sepuh, atau dengan istilah-istilah yang langsung menyebut komoditi jenis lapisan seperti, nickel untuk lapisan nickel, verkrom untuk lapisan chrome dan lain-lain. Electroplating adalah proses pelapisan logam diatas logam dengan bantuan arus listrik. Oleh karena itu logam yang akan dilapisi harus mempunyai sifat konduktor.

Dalam teknologi pengerjaan logam proses electroplating/proses lapis listrik termasuk ke dalam proses pengerjaan akhir (metal finishing). Fungsi utama dari pelapisan logam adalah memperbaiki penampilan (decoratif) misalnya : bahan sebagai pelapisnya adalah emas, perak, kuningan, dan tembaga. Juga memperbaiki kehalusan atau bentuk permukaan dan toleransi logam dasar, misalnya ; pelapisan nickel, chromium. Selain itu juga melindungi logam dasar dari korosi baik itu melindungi dengan logam yang lebih mulia seperti pelapisan platina, emas dan baja atau melindungi dengan logam dasar yang kurang mulia seperti pelapisan seng pada baja dan terakhir adalah meningkatkan ketahanan produk 
terhadap gesekan (abrasi), misalnya pelapisan chromium keras.

\section{LANDASAN TEORI}

\section{A. Prinsip Dasar Electroplating}

Ahmad, 2011. Prinsip dasar dari proses lapis listrik berpedoman atau berdasarkan pada HUKUM FARADAY yang menyatakan : Jumlah zat-zat (unsur-unsur) yang terbentukdan terbebas pada elektroda selama elektrolisa sebanding dengan jumlah arus listrik yang mengalir dalam larutanelektrolit. Jumlah zat-zat (unsurunsur) yang dihasilkan oleh arus listrik yang sama selama elektrolisa adalah sebanding dengan berat ekivalen masingmasing zat tersebut. Pernyataan tersebut dapat ditulis dengan rumus sebagai berikut

Keterangan:

$$
B=\frac{\text { I.t.e }}{F}
$$

$\mathrm{B}=$ Berat zat yang terbentuk (gr)

$\mathrm{I}=$ Jumlah arus yang mengalir $(\mathrm{A})$

$\mathrm{T}=$ waktu (detik)

e =berat ekivalen zat yang dibebaskan

(berat atom suatu unsur dibagi valensi unsur tersebut).

$\mathrm{F}=$ Jumlah arus yang diperlukan untuk membebaskan sejumlah gram ekuivalen suatu zat

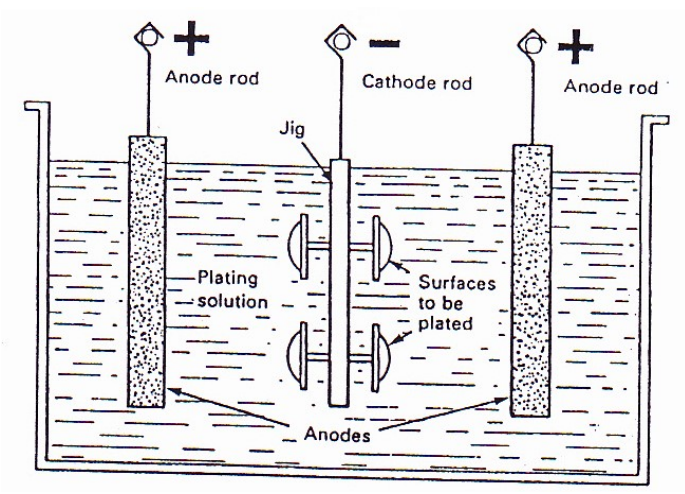

Gambar 1. Skema Electroplating

Danang, 2013. Hukum Faraday sangat hubungannya dengan efisiensi arus yang terjadi pada proses pelapisan secara listrik. Efisiensi arus adalah perbandingan berat endapan yang terjadi dengan berat endapan secara teoritis dan dinyatakan dalam persen. Dalam proses lapis listnk, arus diinginkan dalam kondisi yang konstan, maksud dari pernyataan tersebut adalah tegangan tidak akan berubah atau terpengaruh oleh besar kecilnya arus yang terpakai. Sehingga untuk memvariabelkan ampere, maka yang divariabelkan hanyalah tahanannya saja, sedangkan voltase-nya tetap.

\section{B. Jenis Pelapisan Logam}

1) Pelapisan Dekoratif

Pelapisan dekoratif bertujuan untuk menambah keindahan tampak rupa/secara tampilan suatu produk atau benda krerja. Pelapisan ini sangat digemari oleh masyarakat karena warna yang cemerlang tidak mudah terkorosi dan dapat bertahan lama.

2) Pelapisan Protektif

Pelapisan protektif bertujuan untuk melindungi logam/benda kerja dari pengaruh korosi yang disebabkan oleh reaksi dengan lingkungan. Hal ini disebabkan karena logam pelapis dapat memutus interaksi dengan lingkungan sehingga akan terhindar dari proses oksidasi.

3) Pelapisan untuk sifat khusus
permukaan

Pelapisan ini bertujuan untuk mendapatkan sifat khusus pada permukaan benda kerja/suatu produk akhir misalnya sifat mekaniknya seperti kekerasan. Selain itu juga dapat mendapatkan sifat fisik yang lebih baik misalnya ketebalan lapisan serta tampak rupa secara tampilan. Dengan kata lain pelapisan ini merupakan paduan antara pelapisan dekoratif dan protektif untuk mendapatkan sifat khusus pada permukaan yang lebih baik. Salah satu pelapisan yang sering diaplikasikan adalah pelapisan dengan krom (Putra, 2012).

\section{Mekanisme Reaksi}

Dalam proses elektrolisa nickel, terjadi reaksi pada katoda, yaitu proses reduksi dari ion nickel dengan bantuan elektron-elektron yang berasal dari sumber arus searah. Reaksi reduksi yang terjadi 


$$
\begin{aligned}
& \text { pada katoda sebagai berikut: } \\
& \mathrm{Ni}^{+}+2 e^{-} \rightarrow \mathrm{Ni} \\
& 2 H^{+}+2 e^{-} \rightarrow H^{2}
\end{aligned}
$$

Reaksi yang terjadi pada anoda sebagaiberikut:

$$
\begin{array}{ll}
\mathrm{Ni} & \rightarrow \mathrm{Ni}^{2+}+2 e^{-} \\
4 \mathrm{OH}^{-} & \rightarrow \mathrm{O}_{2}+2 \mathrm{H}_{2} \mathrm{O}+4 e^{-} \\
2 \mathrm{Cl}^{-} & \rightarrow \mathrm{Cl}_{2}+2 e^{-}
\end{array}
$$

Dalam proses elektroplating Krom, yang terjadi reaksi kimia pada katoda dan anoda adalah sebagai berikut :

Reaksi yang terjadi pada katoda :

$$
\begin{array}{ll}
2 \mathrm{H}^{+}+2 e^{-} & \rightarrow \mathrm{H}_{2} \\
2 \mathrm{CrO}_{3}+12 \mathrm{H}^{+}+6 e^{-} & \rightarrow 2 \mathrm{Cr} 3++6 \mathrm{H} 2 \mathrm{O} \\
2 \mathrm{CrO}_{3}+12 \mathrm{H}++12 \mathrm{e}- & \rightarrow 2 \mathrm{Cr}+6 \mathrm{H} 2 \mathrm{O}
\end{array}
$$

\section{Nickel - Chrome}

Nickel adalah logam yang berwarna perak keabu-abuan mempunyai sel satuan kubus berpusat muka $(f c c)$ dengan masa jenis 8,7, hampir sama dengan $\mathrm{Cu}$. Setelah penganilan kekuatan tariknya 45-55 $\mathrm{kgf} / \mathrm{mm}^{2}$, perpanjangannya $40-50 \%$, dan kekerasannya 80-90 Brinell. Ni baik sekali dalam ketahanan panas dan ketahanan korosinya, tidak rusak oleh air kali atau air lautdan alkali. Tetapi bisa rusak oleh asam nitrat dan sedikit tahan korosi terhadap asam khlor dan asam sulfat. Seperti telah dikemukakan di atas $\mathrm{Ni}$ dipergunakan sebagai unsur paduan untuk baja, paduan tembaga, dan paduan nickel tahan panas. Nickel sendiri dibuat dalam bentuk pelat tipis batangan pendek, pipa dan kawat, yang dipakai untuk pembuatan tabung elektron dan penggunaan dalam industri makanan. Juga dipakai untuk paduan Ni khusus yang dinamakan kuprorikel untuk pembuatan uang logam. (Surdia, 1999, Pengetahuan Bahan Teknik).

\section{1) Pelapisan Nickel}

Basmal, 2012. Pelapisan nickel digunakan untuk tujuan mencegah korosi ataupun menambah keindahan. Senyawa nickel digunakan terutama sebagai katalis dalam electroplating pada proses electroplating, dengan pelapis nickel (anoda), perlu ditambahkan garam ke bak plating, misalnya nickel karbonat, nickel chlorida, nickel fluoborat, nickel sulfamat dan nickel sulfat.

Saat anoda dan katoda terjadi perubahan potensial akibat aliran arus listrik searah maka anoda nickel terurai ke dalam elektrolit. Reaksi pada katoda yaitu plat baja mengalami pelepasan oksigen ke elektrolit nickel (NiSO4) sehingga ion nickel (Ni) akan menempel dipermukaan baja. Sementara itu reaksi pada anoda nickel (Ni), mengikat oksigen yang dilepas oleh plat baja dan terlarut pada elektrolit nickel (NiSO4) yang telah melapisi plat sehingga larutan elektrolit nickel tetap stabil.

Chromium/krom adalah termasuk bahan logam nonferro yang dalam tabel periodik termasuk grup Vib dan diberi lambang $\mathrm{Cr}$.

\section{2) Pelapisan Chromium}

Ahmad, 2011. Selain nickel maka pelapisan chrome banyak dilaksanakan untuk mendapatkan permukaan yang menarik. Karena sifat khas chrome yang sangat tahan karat maka pelapisan chrome mempunyai kelebihan tersendiri bila dibandingkan dengan pelapisan Iainnya. Selain sifat dekoratif dan atraktif dari pelapisan chrome, keuntungan lain dari pelapisan chrome adalah dapat dicapainya hasil pelapisan yang keras. Sumber logam chrome didapat dari asain chrome, tapi dalam perdagangan yang tersedia adalah chrome oksida (Cr203) yang berbentuk serbuk. Prinsip dasar pelapisan chrom adalah perpindahan partikel dari plat anoda ( yang terhubung dengan kutub positif $(+)$ sumber arus) dengan plat katoda ( benda kerja/benda yang akan di chrom yang 
terhubung dengan kutub negatif (-) sumber arus ) melalui media larutan kimia.

\section{METODE PENELITIAN}

\section{A. Bahan dan Alat Penelitian}

Bahan yang dipakai pada penelitian ini adalah plat baja karbon rendah, seperti di tunjukan Gambar 2 di bawah ini:
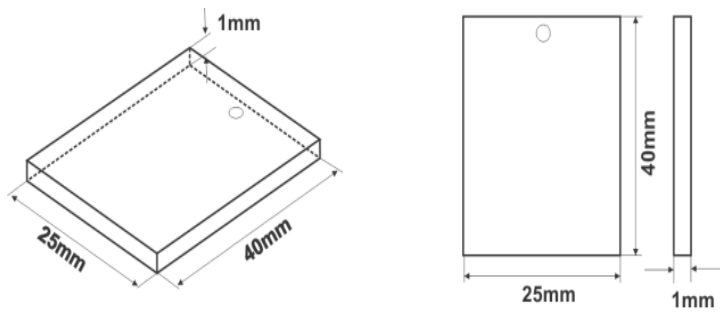

Gambar 2. Bentuk dan ukuran spesimen

Yang mempunyai komposisi kimia sebagai berikut:

Tabel 1. Komposisi kimia spesimen

\begin{tabular}{|c|c|c|c|c|c|c|c|}
\hline Grade & $\mathrm{C} \%$ & $\mathrm{Mn} \%$ & $\mathrm{~S}$ & $\mathrm{~N}$ & $\mathrm{Cu}$ & $\mathrm{Nb}$ & $\mathrm{Ti}$ \\
\hline \multirow{4}{*}{ ST 45 } & $0,08-0,2$ & $0,90-1,50$ & 0,015 & 0,012 & 0,30 & 0,020 & 0,03 \\
\cline { 2 - 8 } & $\mathrm{Si}$ & $\mathrm{P}$ & $\mathrm{Al}$ & $\mathrm{Cr}$ & $\mathrm{Mo}$ & $\mathrm{Ni}$ & $\mathrm{Vi}$ \\
\cline { 2 - 8 } & 0,40 & 0,025 & 0,020 & 0,30 & 0,08 & 0,30 & 0,02 \\
\hline
\end{tabular}

Peralatan penelitian yang dipakai antara lain:

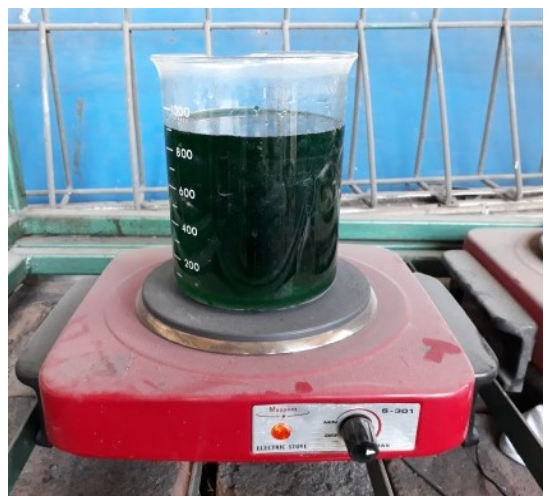

Gambar 3. Cairan nikel

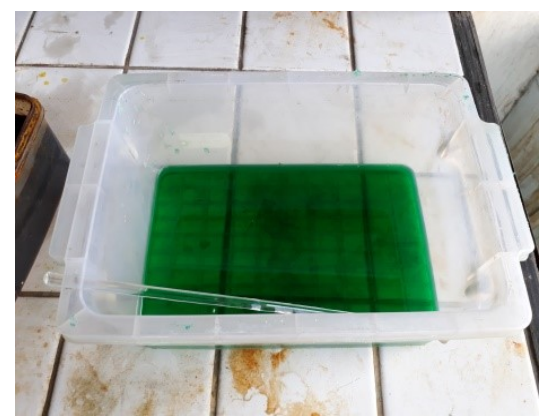

Gambar 4. Cairan nikel

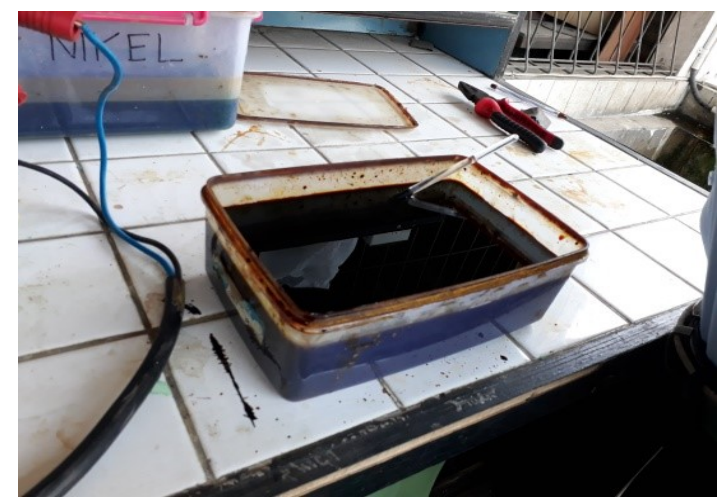

Gambar 5. Cairan krom

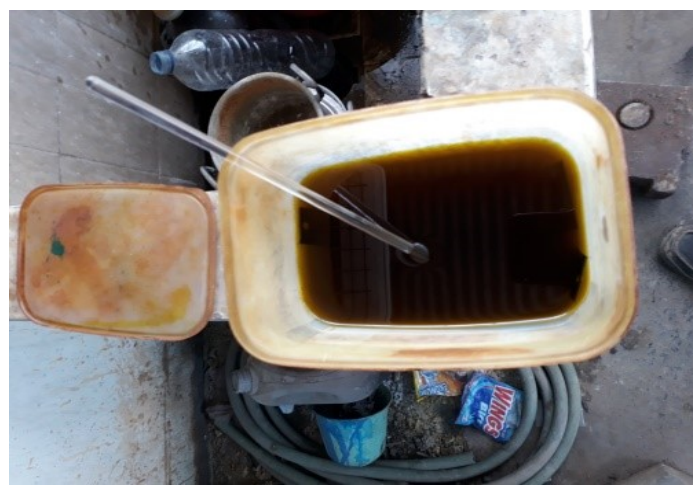

Gambar 6. Larutan HCL

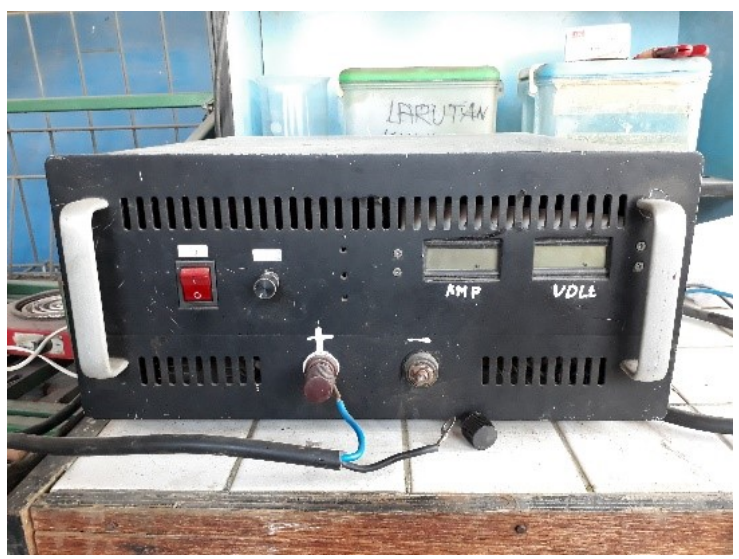

Gambar 7. Alat electroplating.

\section{B. Tahapan Penelitian}

Adapun tahap penelitian yang akan dilakukan dalam rangka mengumpulkan data hingga penyelesaian masalah dalam penelitian ini adalah sebagai berikut:

Mempersiapkan bahan, dalam hal ini plat baja, nikel dan krom cair. Pembuatan spesimen, memotong pelat baja dengan dimensi $25 \mathrm{~mm} \times 40 \mathrm{~mm}$ x $1 \mathrm{~mm}$ sampai jumlah total 36 specimen. Mencampur larutan nikel dengan volume 1 liter, pada bak dengan dimensi $21 \mathrm{~cm} \times 12 \mathrm{~cm}$ x 10 
cm. Membersihkan benda uji dengan larutan HCL dan Polishing specimen. Proses Pelapisan listrik (Electroplating). Menyiapkan larutan nikel yang akan digunakan sebanyak 1 liter. Memanaskan larutan nikel dan krom hingga mencapai suhu $40-60^{\circ} \mathrm{C}$. Masukkan larutan nikel ke dalam beaker glass dengan kapasitas $>1$ liter. Memasukkan specimen kedalam bak larutan nikel sebagai pelapisan yang pertama dan larutan krom sebagai pelapisan kedua hingga spesimen terendam sepenuhnya didalam larutan Menghubungkan benda kerja yang akan dilapisi dengan pembangkit arus searah pada kutub yang bermuatan negatif (katoda). Menghubungkan bahan yang digunakan untuk melapisi dengan kutub bermuatan positif (anoda). Melakukan tahap pelapisan electroplating nikel sebagai lapisan pertama atau lapisan dasar pada specimen dengan ketentuan sebagai berikut: Spesimen dengan jumlah 36 spesimen yang telah disiapkan dicelupkan ke dalam larutan elektrolit pada waktu 10 menit dengan arus 0,5A. Melakukan tahap pelapisan electroplating chrome sesuai dengan waktu dan temperatur yang telah ditentukan. Spesimen dengan jumlah 4 spesimen yang telah disiapkan dicelupkan ke dalam larutan elektrolit pada waktu 10 menit serta dengan variasi arus $0,5 \mathrm{~A}, 1 \mathrm{~A}$, dan 1,5 A. Dengan cara yang sama, 4 spesimen berikutnya dicelupkan ke dalam larutan elektrolit pada waktu 15 menit. Kemudian 4 spesimen terakhir dicelupkan dengan waktu 20 menit. Menjaga arus agar tetap stabil pada arus yang telah ditentukan. Mengangkat specimen setelah waktu yang ditentukan. Mencatat volt meter, ampere, waktu dan suhu proses electroplating. Polishing, dengan menggunakan alat poles kain yang bertujuan untuk mengkilapkan dan menghaluskan permukaan specimen. Membersihkan specimen dengan air dan kemudian mengeringkan specimen agar sisa air tidak mengendap pada permukaan specimen.

\section{HASIL DAN PEMBAHASAN}

\section{A. Pengaruh arus 0.5 A dan waktu terhadap ketebalan lapisan permukaan baja karbon rendah}

Hasil uji ketebalan pada benda kerja yang telah dilapisi nickel-chrome dengan metode electroplating dengan variasi arus $0.5 \mathrm{~A}, 1 \mathrm{~A}$, dan 1.5 A. Ketebalan rata-rata untuk pelapisan nickel-chrome dengan variasi kuat arus dan waktu tersebut dapat dilihat pada tabel 2:

Tabel 2. Data hasil pengukuran ketebalan hasil pelapisan

Spesimen Baja Karbon Lapis Nikel - Chrom, Variasi Arus Listrik dan Waktu
\begin{tabular}{|c|c|c|c|c|c|c|}
\hline \multirow{2}{*}{ No } & \multirow{2}{*}{ Kode } & \multirow{2}{*}{ Posisi titik uji } & \multicolumn{4}{|c|}{ Tebal Lapisan $(\mu \mathrm{m})$} \\
\cline { 5 - 7 } & & & 1 & 2 & 3 & Rata-rata \\
\hline 1 & A $0.5-10$ & Acak & 1.1 & 1.5 & 1.1 & 1.23 \\
\hline 2 & A $0.5-15$ & Acak & 1.2 & 1.8 & 1.4 & 1.47 \\
\hline 3 & A $0.5-20$ & Acak & 1.2 & 1.3 & 1.1 & 1.20 \\
\hline 4 & A $1.0-10$ & Acak & 1.3 & 1.7 & 1.3 & 1.43 \\
\hline 5 & A $1.0-15$ & Acak & 1.5 & 2.0 & 1.9 & 1.80 \\
\hline 6 & A $1.0-20$ & Acak & 1.3 & 1.2 & 1.1 & 1.20 \\
\hline 7 & A $1.5-10$ & Acak & 2.4 & 1.5 & 1.1 & 1.67 \\
\hline 8 & A $1.5-15$ & Acak & 1.5 & 1.5 & 1.4 & 1.47 \\
\hline 9 & A $1.5-20$ & Acak & 1.7 & 2.3 & 1.90 & 1.97 \\
\hline
\end{tabular}

Dari tabel 2 dapat dibuat grafik kurva hubungan waktu dan kuat arus terhadap ketebalan lapisan seperti pada gambar 9 dibawah ini:

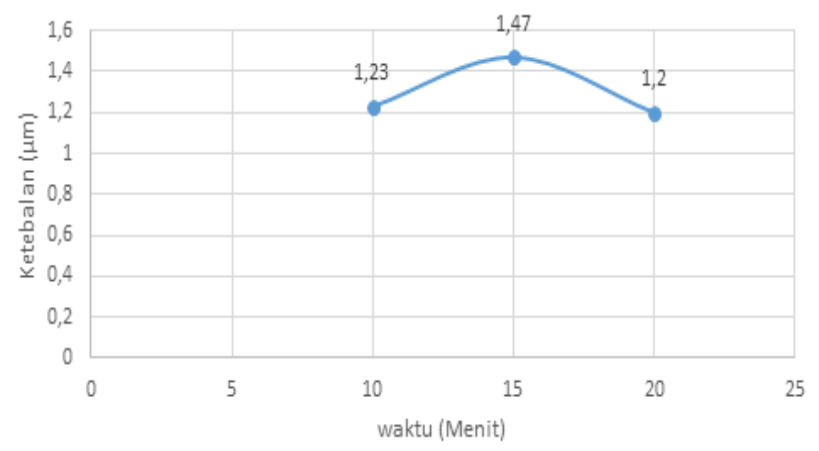

Gambar 8. Grafik pengaruh arus 0.5A dan waktu terhadap ketebalan lapisan permukaan baja karbon rendah

Dari grafik diatas menunjukan adanya kenaikan ketebalan yang secara keseluruhan cukup signifikan pada menit ke 15 merupakan nilai ketebalan maksimal dengan nilai ketebalan $1.47 \mu \mathrm{m}$, namun pada menit selanjutnya mengalami 
penurunan nilai ketebalan. Hal ini bisa dimungkinkan karena adanya logam-logam berat seperti besi dan mangan sebagai pengotor yang dapat menimbulkan cacatcacat pada permukaan.

\section{B. Pengaruh arus 1A dan waktu terhadap ketebalan lapisan permukaan baja karbon rendah.}

Hasil pengujian ketebalan lapisan krom di tunjukan Gambar 10 dibawah ini.

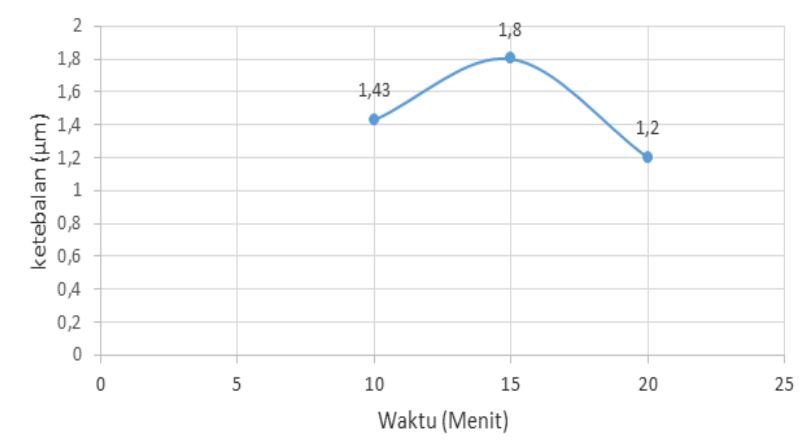

Gambar 9. Grafik pengaruh arus 1A dan waktu terhadap ketebalan lapisan permukaan baja

karbon rendah

Pada varian ini sama halnya dengan grafik sebelumnya yaitu terjadi peningkatan dengan nilai ketebalan $1.43 \mu$ dan menit ke 15 menjadi titik maksimum ketebalan lapisan dengan nilai ketebalan $1.8 \mu \mathrm{m}$ dan pada menit selanjutnya terjadi penurunan dengan nilaiketebalan $1.2 \mu \mathrm{m}$ ketebalan pada menit ini menjadi nilai ketebalan paling rendah yang terjadi pada varian dengan arus 1 A yaitu pada menit ke 20 .

\section{Pengaruh arus $1.5 \mathrm{~A}$ dan waktu terhadap ketebalan lapisan permukaan baja karbon rendah.}

Dari Grafik hubungan pengaruh waktu terhadap ketebalan lapisan pada proses electroplating nickel-chrome diatas, menunjukkan pencelupan dengan penggunaan waktu 10 menit pada arus masing-masing $0.5 \mathrm{~A}, 1 \mathrm{~A}$, dan $1,5 \mathrm{~A}$ mengalami peningkatan, dengan nilai ketebalan lapisan sebesar $1.23 \mu \mathrm{m}, 1.43 \mu \mathrm{m}$, dan $1.67 \mu \mathrm{m}$. Dan untuk penggunaan waktu 15 menit sebesar $1.47 \mu \mathrm{m}, 1.80 \mu \mathrm{m}$, dan $1.97 \mu \mathrm{m}$. Hasil pengujian ketebalan lapisan krom di tunjukan Gambar 10 dibawah ini:

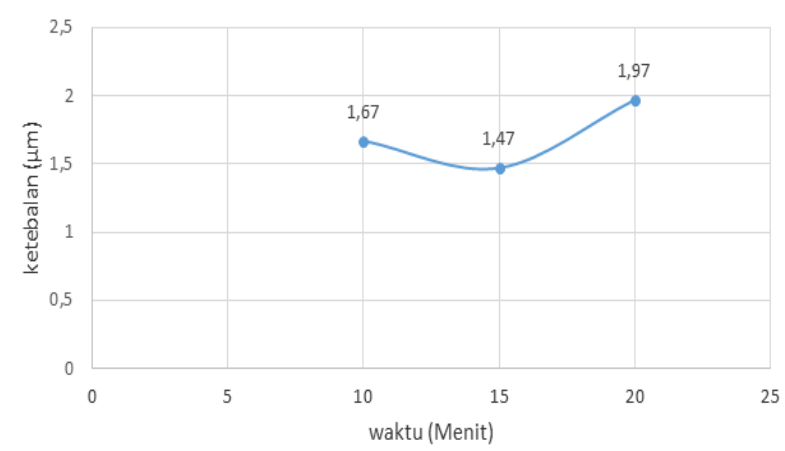

Gambar 10. Grafik pengaruh arus 1,5A dan waktu terhadap ketebalan lapisan permukaan baja

Kecuali pada penggunaan waktu 20 menit dengan arus $0.5 \mathrm{~A}$ dan $1.5 \mathrm{~A}$ ketebalan lapisan mengalami penurunan dibandingkan dengan waktu sebelumnya yakni dengan nilai ketebalan lapisan sebesar $1.20 \mu$ mdan $1.20 \mu \mathrm{m}$. Penurunan ketebalan ini dikarenakan pada waktu 15 menit dengan arus $0.5 \mathrm{~A}$ dan $1.5 \mathrm{~A}$ adalah waktu optimal saat proses pencelupan berlangsung sehingga pada waktu 20 menit ketebalan lapisan mengalami penurunan. Untuk nilai ketebalan lapisan tertinggi diperoleh pada waktu pencelupan dengan waktu 20 menit dengan arus $1.5 \mathrm{~A}$ yaitu dengan nilai ketebalan $1.97 \mu \mathrm{m}$ dan ketebalan lapisan terendah pada waktu pencelupan 20 menit dengan arus $0.5 \mathrm{~A}$ dan 1 A dengan nilai ketebalan $1.20 \mu \mathrm{m}$.

Dari Grafik hubungan pengaruh kuat arus listrik terhadap ketebalan lapisan pada proses electroplating nickel-chrome diatas, menunjukkan pencelupan dengan kekuatan arus listrik 0,5 A pada waktu masingmasing 10 menit, dan 15 menit mengalami peningkatan, dengan nilai ketebalan lapisan sebesar $1.23 \mu \mathrm{m}$, dan $1.47 \mu \mathrm{m}$. Dan untuk penggunaan kekuatan arus listrik 1 A dengan variasi waktu 10 menit dan 15 menit memiliki nilai ketebalan sebesar $1.43 \mu \mathrm{m}, 1.80 \mu \mathrm{m}$. Dan untuk penggunaan kekuatan arus listrik 1,5 A dengan variasi waktu 10 menit dan 20 menit memiliki nilai ketebalan sebesar $1.67 \mu \mathrm{m}$, dan $1.97 \mu \mathrm{m}$ dengan meningkatnya kuat arus 
listrik yang mengalirakan menyebabkan jumlah ion-ion semakin banyak, kecuali pada penggunaan arus $0.5 \mathrm{~A}$ dan $1.5 \mathrm{~A}$ waktu 20 menit ketebalan lapisan mengalami penurunan dibandingkan dengan waktu sebelumnya yakni dengan nilai ketebalan lapisan sebesar $1.20 \mu \mathrm{m}$ dan $1.20 \mu \mathrm{m}$. hal tersebut bisa dimungkinkan karena rapat arus yang tidak sesuaidan membuat proses pengendapan kurang mengikat dengan kuat, sehingga menyebabkan endapan tidak bisa terjadi dengan maksimal bahkan terjadi pula ion-ion yang sudah mengendap kembali berjatuhan dan berguguran. Fenomena tersebut bisa terjadi salah satunya disebabkan oleh larutan elektrolit yang sudah jenuh atau kontaminasi pada larutan elektrolit sehingga pada proses pelapisan kurang maksimal karena pengikat ion-ion elektrolit menjadi deposit.

\section{KESIMPULAN}

Berdasarkan analisa data dan pembahasan yang telah dilakukan, maka dapat diambil kesimpulan sebagai berikut :

A. Ketebalan spesimen hasil proses electroplating semakin meningkat seiring bertambahnya arus dan waktu yang diberikan atau dapat dikatakan berbanding lurus dengan naiknya arus dan waktu, baik secara teoritis maupun pengamatan. Dimana nilai ketebalan teringgi dengan kuat arus $1.5 \mathrm{~A}$ dan waktu 20 menit adalah $1.97 \mu \mathrm{m}$.

B. Dari semua pengujian di atas dapat di simpulkan bahwa variasi kuat arus dan waktu berpengaruh terhadap ketebalan dan kekerasan.

\section{DAFTAR PUSTAKA}

Ahmad, Muhammad Azhar. 2011. Analisa Pengaruh Besar Tegangan Listrik Terhadap Ketebalan Pelapisan Chrom Pada Pelat Baja Dengan Proses Elektroplating, "Tugas Akhir Jurusan
Mesin Fakultas Teknik Universitas Hasanuddin Makassar".

Basmal, dkk. Pengaruh Suhu dan Waktu Pelapisan Tembaga-Nikel Pada Baja Karbon Rendah Secara Elektroplating Terhadap Nilai Ketebalan dan Kekerasan", "Rotasi : Jurnal Teknik Mesin, Volume 14, No. 2, April 2012"

Darmawan, Arif Surya, dkk. Pengaruh Variasi Kuat Arus Listrik dan Waktu Proses Electroplating Terhadap Kekuatan Tarik, Kekerasan dan Ketebalan Lapisan Pada Baja Karbon Rendah Dengan Krom, "Jurnal Dhamika Teknik Mesin, Volume 5, No.2, Juli 2015 ISSN: 2088-088X".

Deviana, Ratih dan Arya Mahendra S. Pengaruh Waktu Pencelupan dan Temperatur Proses Elektroplating Terhadap Ketebalan dan Kekerasan Permukaan Baja ST42, "Jurnal Teknik Mesin, Volume 03, No. 01, 2014".

Pangajuanto, Teguh dan Tri Rahmidi. 2009. KIMIA 3. Jakarta: Departemen Pendidikan Nasional

Putra, Florentinus Ardika S. 2014. Pengaruh Waktu dan Tegangan Pada Lapisan Hard Chrome Terhadap Kekerasan Baja Karbon Rendah, "Tugas Akhir Program Studi Teknik Jurusan Teknik Mesin Fakultas Sains dan Teknologi Universitas Sanata Dharma".

Putra, Fransiskus Sukma A. 2012. Pengaruh Arus dan Waktu Pelapisan Hard Chrome Terhadap Ketebalan Lapisan dan Kekerasan Pada Plat Baja Karbon Rendah Aisi 1026 
Dengan Elektroplating Menggunakan $\mathrm{HCrO}_{3} 250 \mathrm{gr} / \mathrm{lt}$ dan $\mathrm{H}_{2} \mathrm{SO}_{4}$ 1,25 gr/lt, "Skripsi Jurusan Teknik Mesin Fakultas Teknik Universitas Sebelas Maret Surakarta".

Raharjo,Samsudi, 2010. Pengaruh Variasi Tegangan Listrik Dan Waktu Proses Electroplating Terhadap Sifat Mekanis Dan Struktur Mikro Baja Karbon Rendah Dengan Krom. "Prosiding Seminar Nasional Universitas Muhammadiyah Semarang”.

Sugiyarta, 2012. Pengaruh Kuat Arus Dan Konsentrasi Larutan Elektrolit Terhadap Ketebalan Pada Pelapisan Nikel Untuk Baja Karbon Rendah, "Masters thesis, Program Pascasarjana Universitas Dipenogoro Semarang”.

Sukrawan, Yusep. Analisis Variasi Waktu Proses Hard Chrome Terhadap Kekerasan Dan Ketebalan Lapisan Pada Besi Cor Kelabu, "Jurnal Torsi Volume 01, No. 01, 2016”.

Surdia, Tata dan Shinroku Saito. 1994. Pengetahuan Bahan Teknik. Cetakan Keempat. Jakarta: Pradnya Paramita.

Susanto, Eko Edy. Analisis Tegangan dan Waktu Pada Proses Elektroplating Nikel-Krom Terhadap Tebal Lapisan", "Jurnal Flywheel Volume 04, No. 02, 2011".

Tarwijayanto, Danang. 2013. Pengaruh arus dan waktu pelapisan hardchrome terhadap ketebalan lapisan dan tingkat kekerasan mikro pada plat baja karbon rendah aisi 1026 dengan menggunakan cro3 250 gr/lt dan h2s04 2,5 gr/lt pada proses elektroplating. "Skripsi jurusan teknik mesin fakultas teknik universitas sebelas maret surakarta".

Yuwono, Akhmad Herman, 2009. Buku Panduan Praktikum Karakterisasi Material 1 Pengujian Merusak (Destructive Testing). Departemen Metalurgi Dan Material Fakultas Teknik Universitas Indonesia. 